\title{
Gender role perspectives and job burnout
}

\author{
Benjamin Artz ${ }^{1} \cdot$ Ilker Kaya $\mathbb{D}^{2} \cdot$ Ozgur Kaya ${ }^{2}$
}

Received: 23 November 2020 / Accepted: 7 August 2021 / Published online: 19 August 2021

(c) The Author(s), under exclusive licence to Springer Science+Business Media, LLC, part of Springer Nature 2021

\begin{abstract}
Women are more likely than men to report physical and emotional exhaustion related to paid work. While this gender gap in job burnout is common in the literature, the mechanism is yet to be thoroughly understood. Our study offers a novel, and admittedly provocative, explanation for the difference in burnout between men and women. We leverage a US survey rich in job and personal information to test whether theoretically relevant factors explain the gender gap in job burnout. Our results suggest that they may not. Instead we find that workers' perspectives regarding women's role in society drive a large gender gap in job burnout. Specifically, "traditional" women are significantly more likely than men to report job burnout. Thus, providing support and resources to transform perceptions and attitudes regarding gender roles may help to reduce job-related burnout resulting from a mismatch between expectations and paid work experiences.
\end{abstract}

Keywords Gender role · Job burnout - Unpaid caregiving and domestic work · Gender gap · Progressive women

JEL Code $\mathrm{J} 00 \cdot \mathrm{J} 16 \cdot \mathrm{D} 19$

\section{Introduction}

Family and work are quite possibly the two primary facets of life. Yet, the role expectations and responsibilities of each may often be intertwined and complicated. The resulting potential conflict between family and work can reduce job and life satisfaction for employees (Ford et al., 2007; Michel \& Hargis, 2008; Carlson et al., 2009). Moreover, competing demands for attention by both paid work and family can

Ilker Kaya

ikaya@aus.edu

1 College of Business, Economics, University of Wisconsin Oshkosh, Oshkosh, WI, USA

2 School of Business Administration, Economics, American University of Sharjah, Sharjah, UAE 
correlate with anxiety, depression and physical and emotional exhaustion (Allen et al., 2000). It is thus not surprising that a rich literature has formed around measuring and analyzing the resulting consequences of these work and family conflicts, often termed job burnout.

The term burnout first emerged in the 1970s as a social problem recognized in the psychological literature (Schaufeli et al., 2009). Burnout can be described as failure, exhaustion or fatigue resulting from excessive demand on one's personal energy, strength, or resources. Accordingly, burnout pertaining to jobs can be regarded as the depletion of workers' resources over time that has been found to be related to certain physical and mental health problems including anxiety, depression and musculoskeletal disorders. Moreover, job burnout corresponds with several undesirable labor outcomes and behaviors such as reduced job satisfaction, productivity, and organizational commitment as well as higher turnover and absenteeism (Nahrgang et al., 2011; Hakanen \& Schaufeli, 2012).

One might presume that job burnout has likely been borne more by women; their labor force participation grew from $32 \%$ in 1948 to $60 \%$ in $2000^{1}$ but their role as the primary worker in unpaid caregiving and domestic work largely remained unchanged $^{2}$. This implies that women may disproportionately suffer from job-related burnout as their resources have likely been strained over time more so than men $^{3}$. In an expansive meta-analysis of over 180 studies, Purvanova and Muros (2010) find that women are more likely to report work-related emotional and physical exhaustion, one aspect of job burnout. However, the literature is not clear whether women report more exhaustion because their experienced conflict between family and work is mainly due to intuitive causal factors like greater workload, or if the reported exhaustion is a result of unrealized expectations or preferences. Indeed, at times the literature identifies the perceived or expected social roles of men and women as a major source of the conflict between work and family (Gutek et al., 1991; Eagle et al., 1997). Analyzing the incidence and severity of job burnout therefore requires investigating workload at job and home as well as other job related aspects in addition to preferences or expectations about gender roles.

In this study, we first contribute to the literature by using unique and somewhat uncommon data. While most studies rely on small survey samples of particular occupations or subsets of the population, our dataset is nationally representative of the US, is rich in demographic, job and personality characteristics, and includes nearly 4200 observations spread across most occupations and industries. Our second

\footnotetext{
1 Taken from the Federal Reserve Economic Data and American Time Use Survey.

2 The literature commonly uses "unpaid work", "care work / caring labor" and "care economy" terminology to identify domestic work that is not priced by the market as production of economic goods and services, and therefore typically not included in measuring gross domestic product (GDP). In our study, we used "unpaid caregiving and domestic work" for the same purpose to reflect the conventional use in the work/life conflict literature and to avoid loss of meaning.

3 This effect may have been even worse during the COVID-19 pandemic. Croda and Grossbard (2021) review some recent articles documenting the high cost of COVID containment policies especially on women. Since the start of the pandemic, women reported a greater deterioration in mental health and lower level of well-being than men (Cheng et al., 2021, Huebener et al., 2021) and a significant number of working women have taken time off or left their jobs to care for their school-aged children (Heggeness, 2020).
} 
contribution is to test for a gender difference in job-related burnout and assess whether the difference exists due to observable heterogeneity in men's and women's lives. Finally, we suggest a novel, and admittedly provocative, explanation for the difference in burnout between men and women. Specifically, we analyze the gendered differences in burnout by focusing on women's own subjective preferences and expectations about gender roles. Indeed, since most measures of burnout rely on selfreported assessments, the preference alignment of women conditional on women's role in society may affect their self-reported job burnout. As such, we uniquely identify workers' preference alignments as "traditional" or "progressive" by using measures in the National Study of the Changing Workforce (NSCW) survey that specifically record workers' social role preferences for women.

We find that women are more likely to report job-related burnout than men, and that observable individual, job and family characteristics do not explain the gender gap. Furthermore, women we identify as "progressive" share an equivalent likelihood with men of experiencing burnout. By contrast, "traditional" women are far more likely to experience burnout. We examine the robustness of our results by using alternative specifications, but these fail to contradict our main results.

While earlier studies propose that improved organizational support may be effective in lowering burnout among women (e.g. Senécal et al., 2001; Tamres et al., 2002; Beauregard, 2011), our study's results suggest that organizational support may be insufficient. If female workers' burnout depends upon their own self-evaluation and perception of women's social role, then other interventions aimed at addressing perceptions of women's role in society may be necessary to reduce the rate of job burnout among women. Consequently, our results may inform new policy designs meant to improve the productivity and wellbeing of, specifically, female workers.

\section{Background and hypotheses}

In most countries men participate more in labor markets than women. Yet, this gender gap in labor force participation has tightened significantly during the last several decades in the US, such that women recently constituted approximately $47 \%$ of the US labor force ${ }^{4}$. The increase in female labor force participation in the US since the 1950s was predominantly driven by married women (Engemann \& Owyang, 2006) and by women with children regardless of marital status (Hipple, 2016). In 1975 more than half (about 53 percent) of US households contained a working father and "stay-at-home" mother, but this proportion fell to less than a third by 2016 (Howard, 1990; BLS, 2017). Despite these notable changes over time in the gender composition of the labor market, the gender roles in unpaid caregiving and domestic work largely remained unchanged. Men still spend more time in paid work while women still spend more time on childcare and household chores ${ }^{5}$. In fact, women in North America spend nearly twice as much time on unpaid caregiving as men (Ferrant et al., 2014). Both paid work and unpaid caregiving lessen the time that can be allocated to relaxation and leisure and therefore critically influence individual

\footnotetext{
${ }^{4}$ Bureau of Labor Statistics (2017)

5 American Time Use Survey (1965-2019)
} 
well-being (MacDonald et al., 2005; Liu et al., 2018). Thus, in studies of job burnout it is important to consider the burden of not only paid work but also domestic work that can intertwine and even disrupt paid work (Qi \& Dong, 2016).

Burnout is a serious problem for economies as it correlates with increased absenteeism, reduced productivity, diminished organizational commitment and higher turnover (Nahrgang et al., 2011; Hakanen \& Schaufeli, 2012). Workers experiencing job burnout are generally less engaged, energetic and connected to their work (Schaufeli et al., 2006). Though the prevalence of job-related burnout in the general workforce is estimated to be between 2 to $13 \%$ at any given time (Ahola et al., 2005; Norlund et al., 2015) and nearly two-thirds of workers have experienced burnout at some point ${ }^{6}$, a confirmed gender gap in job-related burnout is elusive. Some studies document that women report higher levels of job burnout (Pines \& Aronson, 1988; Toker et al., 2005). Others conclude the opposite by documenting higher levels of job burnout among men (Zani \& Pietrantoni, 2001; Brake et al., 2003). Still other studies find no dissimilarities in burnout among men and women (e.g., Greenglass, 1991; Benbow \& Jolley, 2002; Jawahar et al., 2007).

These heterogeneous results regarding gender and burnout may be due to many differences between studies. First, sample sizes are often quite small. Second, at times studies compare female and male samples from different populations. Third, some studies compare men and women holding different occupations. Similarly, gender differences in management / supervisory positions, education levels, or social, economic or political standing confound the relationship between gender and burnout (Greenglass, 1991, Sulsky \& Smith, 2005; Maslach et al., 2008). At a minimum, Malach-Pines and Ronen (2016) suggest that the pathway to identifying the gender differences in burnout has been inconsistent. Accordingly, a significant cause of the inconsistency may be differences in burnout definitions. Some studies define burnout as involving depersonalization behaviors, or withdrawal from job tasks, whereas most define burnout as an emotional or physical exhaustion. In a comprehensive meta-analysis, Purvanova and Muros (2010) find in over 180 studies that men are more likely to report depersonalization-type burnout while women are more likely to report exhaustion-type burnout. Consequently, we follow the majority of the literature and define burnout using the exhaustion measure. Following the Purvanova and Muros (2010) result, we hypothesize that women are more likely than men to report symptoms of job-related burnout.

Yet another rationale for the contradictions in the literature, and one that remains unexplored in its relationship to burnout (to our knowledge), stems from the difference between biological sexes and socially influenced gender roles. Gender is a more nuanced construct than biological sexes, and it is influenced by social factors, at least in part. Societies assign different standards, rules, rights, responsibilities, and values to the genders given their biological and physiological differences (Suar \& Gochhayat, 2016). Hence, societies expect a distinctive set of values, attitudes, and behaviors from genders (Messner, 2000) to the extent that people may recognize or define their own gender to be aligned with traditional social expectations by gender (Livingston \& Judge, 2008). Individuals start to learn these societal gender

\footnotetext{
${ }^{6}$ https://www.gallup.com/workplace/237059/employee-burnout-part-main-causes.aspx. December 15, 2019.
} 
expectations at very early ages from their family, friends, and community members as well as from schools and other public, cultural, faith, and work-related organizations (Rittenour et al., 2014; Suar \& Gochhayat, 2016). Nevertheless, distinct gender roles can jointly exist in women who can hold customary masculine roles, and men who can hold traditional feminine roles (Bem, 1974; Suar \& Gochhayat, 2016). Indeed, in modern societies the gender roles for men and women share increasingly common characteristics and are slowly merging. Women's strengthening economic role has been the main driving force for challenging the cultural notion that women should mainly provide unpaid house and family care services whereas men should primarily be responsible for producing income.

This study contributes to the literature by attempting to explain gender differences in burnout by focusing on women's own subjective expectations or preferences regarding gender roles. For example, women who expect or believe a "traditional" role for women in the family is best may prefer to spend more time at home with their children and family. Any additional work or challenges related to their paid jobs may be realized as additional burden (assuming that having a paid job outside the home is not their first preference). That is why they may report higher levels of burnout. Likewise, women who perceive that a "progressive" role for women is best may be more likely to be neutral, but less conflicted or prefer spending more time in paid work. Additional jobrelated burdens are therefore expected and do not lead to reporting higher levels of burnout. We do not anticipate similar variation among men since working for pay tends to align with both traditional and progressive social roles for men. In short, we hypothesize that women will perceive or experience burnout differently depending upon their preferences or ideologies related to work, but men will not.

We choose to focus on these gender related differences for two reasons. First, there are arguments that burnout is more of a female experience (Maslach et al., 2001). This may be related to the assumption that women tend to burn out more due to role overload (having too much to do) and/or role conflict (multiple roles with conflicting demands), even though there are mixed results in the academic literature. Accordingly, gender differences may be exaggerated to women's disadvantage, which could lead to inflated and costly claims (Hyde, 2005). If women are assumed to be more susceptible to burnout than men by their coworkers, peers and superiors, they may be passed up for challenging assignments and promotions. Second, if burnout is considered to be mainly a female experience, men may not seek and receive adequate attention when they feel burned out (Purvanova \& Muros, 2010). Men may feel it would be socially unacceptable to openly express vulnerability and confide that they have "feminine" feelings (David \& Brannon, 1976). Therefore, if gender differences in burnout exist, we are interested in capturing where these differences potentially stem from.

\section{Data and method}

Our study relies on US survey data from the National Study of the Changing Workforce (NSCW), originally collected by The Families and Work Institute (FWI), 
a nonprofit organization ${ }^{7}$. The NSCW is a major study of the U.S. workforce targeting employees' lives both on and off the job and contains data formed by nationally representative surveys generally repeated about every five to six years. Our study employs respondents from the 2002 and 2008 cohorts of the NSCW surveys. We pool these two waves as they both contain demographic and job characteristics drawn from identically worded questions. These variables include gender, race, age, education, marital status, number of children, spousal employment, pension, health insurance, vacation days, paid-time-off, flexible work hours, union membership, employer tenure, weekly hours worked, wages and sector of employment. After removing all military observations and those with incomplete data, the pooled working sample size is 4173 observations. In order to further improve how well the data represent the population, we utilize survey weights and estimation throughout. We present all variable definitions and descriptive statistics in Table 1.

The NSCW is of particular value to our study due to its provision of burnout measures. The literature is replete with different forms of burnout, but there is some evidence of studies coalescing around exhaustion and emotional distress as two primary forms. For instance, Maslach et al. (1986) suggest that emotional exhaustion and distress alongside deficiency of energy are central components of burnout while Houtman and Blatter (2005) also note that many workers persistently absent from jobs are commonly identified as overstrained and emotionally depressed and exhausted. Thus we use respondent data from the NSCW that we feel best encapsulate these common notions of burnout from the existing literature.

The literature likewise offers a variety of burnout metrics that tend to vary by the available data. The most commonly used measure of burnout is the Maslach Burnout Inventory (MBI). The MBI is characterized by emotional exhaustion, depersonalization and diminished personal accomplishment from work (Maslach \& Leiter, 2016). Other widely used measures include the Bergen Burnout Inventory (Maarit et al., 2013), Oldenburg Burnout Inventory (Halbesleben \& Demerouti, 2005), Shirom-Melamed Burnout Measure (Shirom, 1989), Copenhagen Burnout Inventory (Kristensen et al., 2005), Burnout Measure (Pines \& Aronson, 1988), or a single-item measure (such as Dolan et al., 2015).

Although the three-dimensional MBI model tends to dominate the research field, there exists a positive regard for the simplicity of a one-dimensional burnout measure within the history of burnout research (Maslach et al., 2008). Accordingly, in a single composite index we weigh equally four items adapted from the NSCW survey that we consider to be translated or modified versions of other burnout scales used in the extant literature mentioned above. While we rely most on the composite measure as our primary dependent variable, we do utilize each individual component in robustness checks as well. The individual measures are Likert scales coded from 1 ("never") to 5 ("very often), with each measure representing worker responses to how often work reduces energy, disrupts life at home, causes feelings of being overwhelmed or prevents good moods. The specific wording to each measure is contained in Table 1. The burnout composite index equally weighs all four burnout measures by simply adding

\footnotetext{
7 Recently, the NSCW became a project of the Society for Human Resource Management (SHRM).
} 
Table 1 Descriptive statistics: mean (standard deviation)

Variables and descriptions
Burnout measures (dependent variables)
Burnout composite index (equal weights) ranges from 4 if
respondent answered "never" to all four component measures
to 20 if respondent answered "very often" to all four
component measures
No energy ranges from 1 if "never" to 5 if "very often" to
the question: "How often have you NOT had the energy to do
things with your family or other important people in your life
because of your job?"
Work disrupt ranges from 1 if "never" to 5 if "very often" to
the question: "How often has work kept you from doing as
good a job at home as you could?"
Overwhelmed ranges from 1 if "never" to 5 if "very often"
to the question: "How often have you felt overwhelmed by
how much you had to do at work in the last three months?"
Bad mood ranges from 1 if "never" to 5 if "very often to the
question: "How often have you NOT been in as good a mood
as you would like to be at home because of your job?"
Demographic characteristics (independent variables)
Female = 1 if respondent is a woman; 0 otherwise

Progressive $=1$ if respondent strongly disagrees with

Statement A or strongly agrees with Statement B ${ }^{\mathrm{a}} ; 0$ otherwise

$2008=1$ if NSCW 2008 wave; 0 if NSCW 2002 wave Hispanic $=1$ if respondent is Hispanic; 0 otherwise

Whole sample

Women

Men

$11.030(3.440)$

$11.146(3.466)$

$10.879(3.401)$

2.641 (1.105)

$2.660(1.107)$

2.615 (1.102)

$2.600(1.106)$

$2.610(1.120)$

2.587 (1.087)

$3.145(1.225)$

$3.224(1.230)$

$3.040(1.211)$

$2.656(1.042)$

$2.652(1.056)$

$2.637(1.021)$

$0.567(0.496)$

$0.582(0.496)$

$0.638(0.481)$

$0.509(0.500)$

$0.510(0.500)$

$0.498(0.500)$

$0.526(0.499)$

0.059 (0.236)

$0.059(0.236)$

0.059 (0.236)

0.090 (0.286)

$0.108(0.310)$

0.067 (0.250)

$0.062(0.240)$

$0.057(0.233)$

$0.067(0.250)$

otherwise

Age in years

43.117 (11.524)

43.486 (11.397)

42.632 (11.674)

$0.328(0.470)$

$0.331(0.471)$

$0.325(0.469)$

degree; 0 otherwise

College $=1$ if respondent has a college degree; 0 otherwise

Post-college $=1$ if respondent has a professional, masters or $\mathrm{PhD} ; 0$ otherwise

Children $=$ number of children under 18 that live with respondent for at least half the year

Age of youngest child = age of youngest child living with respondent for at least half the year

Chore time $=$ average time in minutes spent on working days on home chores like cooking, cleaning, yard work, etc.

Childcare time $=$ average time in minutes spent on working days taking care of or doing things with their children

Expected spousal income $=$ expected annual earnings of

$0.266(0.442)$

$0.278(0.448)$

$0.250(0.433)$

$0.165(0.371)$

$0.158(0.364)$

$0.174(0.380)$

$0.802(1.094)$

$0.770(1.061)$

$0.843(1.133)$

$2.722(5.989)$

$2.857(6.148)$

$2.546(5.771)$

$142.803(120.701)$

$155.796(121.155) \quad 125.773(117.989)$

$79.934(185.522)$

$88.484(219.977)$

$68.728(126.103)$

$0.244(0.392)$

$0.280(0.408)$

$0.197(0.365)$

$0.524(0.500)$

$0.488(0.500)$

Spouse works $=1$ if respondent has a spouse or partner who works for pay; 0 otherwise

Spouse prefers not to work $=1$ if respondent has a spouse or partner who prefers not to work for pay ${ }^{b}$

Spouse is unable to work $=1$ if respondent has a spouse or $0.067(0.251)$

$0.041(0.198)$

$0.145(0.352)$

$0.054(0.225)$

$0.085(0.279)$ partner who is unable to work for pay ${ }^{\mathrm{c}}$

10 regions

Geographic regions:

$0.595(0.491)$

$0.578(0.494)$

$0.619(0.486)$ 
Table 1 continued

\begin{tabular}{|c|c|c|c|}
\hline Variables and descriptions & Whole sample & Women & Men \\
\hline $\begin{array}{l}\text { Insurance }=1 \text { if employer offers health insurance; } 0 \\
\text { otherwise }\end{array}$ & $0.869(0.337)$ & $0.850(0.358)$ & $0.895(0.307)$ \\
\hline $\begin{array}{l}\text { Vacation }=1 \text { if employer provides vacation days; } 0 \\
\text { otherwise }\end{array}$ & $0.812(0.391)$ & $0.786(0.410)$ & $0.845(0.362)$ \\
\hline $\begin{array}{l}\text { PTO }=1 \text { if employer provides paid-time-off for sickness or } \\
\text { other needs; } 0 \text { otherwise }\end{array}$ & $0.699(0.459)$ & $0.710(0.454)$ & $0.685(0.465)$ \\
\hline $\begin{array}{l}\text { Easy time off }=1 \text { if respondent finds it to be easy to ask for } \\
\text { time off when needed; } 0 \text { otherwise }\end{array}$ & $0.624(0.484)$ & $0.597(0.491)$ & $0.660(0.474)$ \\
\hline $\begin{array}{l}\text { Flexible time }=1 \text { if respondent can choose starting and } \\
\text { ending hours; } 0 \text { otherwise }\end{array}$ & $0.457(0.498)$ & $0.439(0.496)$ & $0.482(0.500)$ \\
\hline $\begin{array}{l}\text { Union }=1 \text { if respondent is a member of a labor union; } 0 \\
\text { otherwise }\end{array}$ & $0.193(0.395)$ & $0.180(0.384)$ & $0.210(0.407)$ \\
\hline Tenure with employer in years & $8.592(8.723)$ & $8.157(8.304)$ & $9.161(9.215)$ \\
\hline Usual weekly work hours & $37.108(8.318)$ & $35.678(8.951)$ & $38.982(6.980)$ \\
\hline Hourly wage & $33.074(77.724)$ & $27.836(60.086)$ & $39.939(95.641)$ \\
\hline $\begin{array}{l}\text { Private sector }=1 \text { if respondent's job is at a for-profit } \\
\text { employer; } 0 \text { otherwise }\end{array}$ & $0.624(0.484)$ & $0.555(0.497)$ & $0.714(0.452)$ \\
\hline $\begin{array}{l}\text { Risk of layoff }=1 \text { if respondent is "very likely" or } \\
\text { "somewhat likely" that during the next couple of years they } \\
\text { will lose their job and have to look for a job with another } \\
\text { employer. }\end{array}$ & $0.256(0.437)$ & $0.240(0.427)$ & $0.279(0.448)$ \\
\hline $\begin{array}{l}\text { High female proportion }=1 \text { if the proportion of respondents } \\
\text { working in each unique industry and occupation intersection } \\
\text { is greater than } 50 \%\end{array}$ & $0.665(0.472)$ & $0.855(0.352)$ & $0.415(0.493)$ \\
\hline Industries: & 12 groups & & \\
\hline Occupations: & 14 groups & & \\
\hline Observations & 4173 & 2367 & 1806 \\
\hline
\end{tabular}

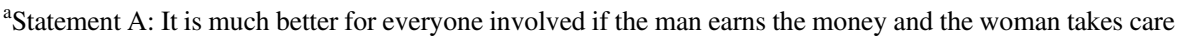
of the home and children

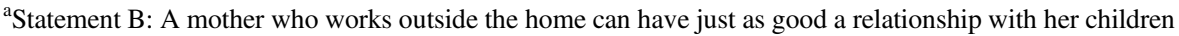
as a mother who does not work

${ }^{b}$ Preferential reasons include taking care of children or other dependents, doing volunteer work, caring for household or pursuing personal interests, or is retired

cInability to work reasons include inability to find a job, is in school or training, cannot afford to work outside the home given dependent care expenses, or is ill, injured or disabled

worker responses together. Thus, the composite measure ranges in value from 4 to 20 and treats each measure of burnout as equally important ${ }^{8}$.

As our measure of burnout is a linear form, we measure gender differences in burnout by estimating Eq. (1) using ordinary least squares (OLS):

$$
\text { burnout }_{i}=\beta_{0}+\beta_{1} \text { Female }_{i}+\beta_{2} \text { Progressive }_{i}+\beta_{3} \bar{X}_{i}+\varepsilon_{i}
$$

The dependent variable is our linear composite measure of burnout, Female $_{i}$ is the respondent's sex, Progressive ${ }_{i}$ is the respondent's ideology, $\bar{X}_{i}$ is a vector of demographic and job characteristics listed in Table 1 and $\varepsilon_{i}$ is the error term. Our attention is mostly placed on the estimates of $\beta_{1}$ and $\beta_{2}$. A significantly positive estimate on the female coefficient suggests women are more likely to report higher

\footnotetext{
8 As the individual measures separately reveal similar results to the composite measure in size, sign and significance, utilizing alternative weighting schemes may not substantially impact our results.
} 
levels of burnout symptoms than men ${ }^{9}$. In addition, a significantly negative estimate on the progressive coefficient suggests ideologically progressive workers are likely to report lower levels of burnout.

Crucial to the purposes of our study, the NSCW provides workers' responses to relevant questions that allow us to uniquely identify workers by their "progressive" or "traditional" ideologies. In our analysis, we scrutinize the gender distinctions in burnout by concentrating on workers' own individual and subjective expectations about gender roles. Specifically, we examine the relationship between "progressive" vs. "traditional" ideologies and burnout. In particular, we record whether workers' perceived gender roles in society may impact their likelihood of burnout by using a combination of two separate variables in the NSCW. We identify "progressive" workers as those who strongly disagree with the statement, "...it is much better for everyone involved if the man earns the money and the woman takes care of the home and children" or those who strongly agree with the statement, "...a mother who works outside the home can have just as good a relationship with her children as a mother who does not work". Approximately 58\% of the full working sample, $51 \%$ of men and $64 \%$ of women are characterized as "progressive".

One can reasonably argue that a non-linear estimator could also be used to estimate Eq. (1) in this instance ${ }^{10}$. However, our primary objective is to determine whether ideological effects vary substantially by gender in their influence on burnout. While gender sub-sample estimates of Eq. (1) can provide important information to that end, they do not immediately provide a statistical test of the comparison. Instead, we primarily utilize interaction terms to statistically analyze the potential gender differences, and OLS is particularly useful when employing interaction terms ${ }^{11}$. Thus, we incorporate interaction terms (between female and all other controls in the model) and estimate Eq. (2) in which the coefficient on the interaction term $\beta_{3}$ indicates whether the gender gap in burnout differs by ideology.

$$
\begin{aligned}
\text { burnout }_{i}= & \beta_{0}+\beta_{1} \text { Female }_{i}+\beta_{2} \text { Progressive }_{i}+\beta_{3} \text { Female }_{i} \\
& \times \text { Progressive }_{i}+\beta_{4} \bar{X}_{i}+\varepsilon_{i}
\end{aligned}
$$

The NSCW contains various information on potential sources of respondents' burnout such as, how much time they spend on childcare and working on chores at home, and how fearful they are of losing their jobs. We control for these in Eq. (2) estimations and interact each with the Female indicator in an effort to identify any gender differences in how these measures impact burnout. With their inclusion, we aim to achieve a more robust measurement of any gender difference in burnout. The

\footnotetext{
9 The position of a man as a breadwinner is still a core aspect of masculinity in many societies despite variations across cultures and demographic classes (Cha \& Thébaud, 2009). Therefore, historically, in most societies, primary breadwinner position in the family is assigned to men, and accordingly we assume that both progressive and traditional men internalize such roles for themselves. Therefore, we do not expect major differences between these two groups for the job expectations and self-reported work related burnout. Thus, our focus in this study predominantly remains on women's burnout.

${ }^{10}$ We do also employ ordered probits of each individual burnout measure as robustness checks in Appendix Table A.

$11 \mathrm{Ai}$ and Norton (2003) suggests that interpretation of interaction term marginal effects in non-linear estimators is problematic.
} 
descriptive statistics for these additional variables for the whole sample as well as by gender are presented in Table 1.

Another potentially interesting nuance in these data are the separate parts of the business cycle that each NSCW wave exhibits. The 2002 data were collected during an expansion and the 2008 data were collected during the Great Recession. It is conceivable that economic and work-related circumstances may affect the level of stress and reported burnout during such difficult times as the Great Recession. Stress factors based on economic slowdown and stagnation may be described as stress factors that appear as a result of economic contraction in workplaces, such as increases in workload and intensity, or changes in job duties and obligations depending on the circumstances. During times of economic turmoil and uncertainty, firms and organizations can respond in various ways that can negatively affect their employees (MacDonald, 2003). For example, many companies may implement downsizing, resulting in increased workloads and responsibilities for the employees who kept their jobs (Parker et al., 1997). It is commonly observed, especially during the Great Recession, that employers squeezed, curbed or modified benefits packages for their employees to cut costs by reducing or abandoning some traditional employee benefits that support worker health, education, or other needs throughout the economic crises (Gunnigle et al., 2013; Cook et al., 2016). Accordingly, we control for the 2008 wave in each estimation and also test if there is a difference by gender in response to the 2008 economic crisis.

\section{Results and discussion}

We first estimate Eq. (1) using OLS and include demographic covariates (i.e. age, race, education), job characteristics (i.e. private-public sector jobs, wage, weekly work hours) and other variables that may be associated with burnout in Table 2, column 1. The regression-adjusted coefficient estimate on the gender indicator implies that women report a statistically significant greater amount of burnout than men do. The Great Recession indicator is significantly positive as well. Older workers also tend to report higher burnout.

Among the results in column 1 of Table 2, of particular interest is how selfreported burnout tends to increase with higher levels of education. The literature is not clear on this relationship since most of the burnout studies use samples from specific jobs or sectors such as teachers (Antoniou et al., 2006; Evers et al., 2004), nurses (Greenglass et al., 2003), doctors (Templeton et al., 2019), academia (Watts \& Robertson, 2011, Johnson et al., 2019) and engineers (Bacharach et al., 1991; Lingard, 2003; Ronen \& Pines, 2008). Moreover, there are few studies of burnout that incorporate education as a control variable. MacDonald et al. (2005) does use education as a covariate but does not report it, instead stating that education is not an important factor in women's stress levels. Yet, Liu et al. (2018) derives a mental health score (MHS) ${ }^{12}$ using a psychological distress scale and finds that education is

\footnotetext{
12 The questions used are (1) Do you feel depressed and like you cannot cheer up? 2) Do you feel nervous? 3) Do you feel agitated or upset and like you cannot remain calm? 4) Do you feel hopeless about the future? 5) Do you feel that everything is difficult? 6) Do you think life is meaningless?)
} 


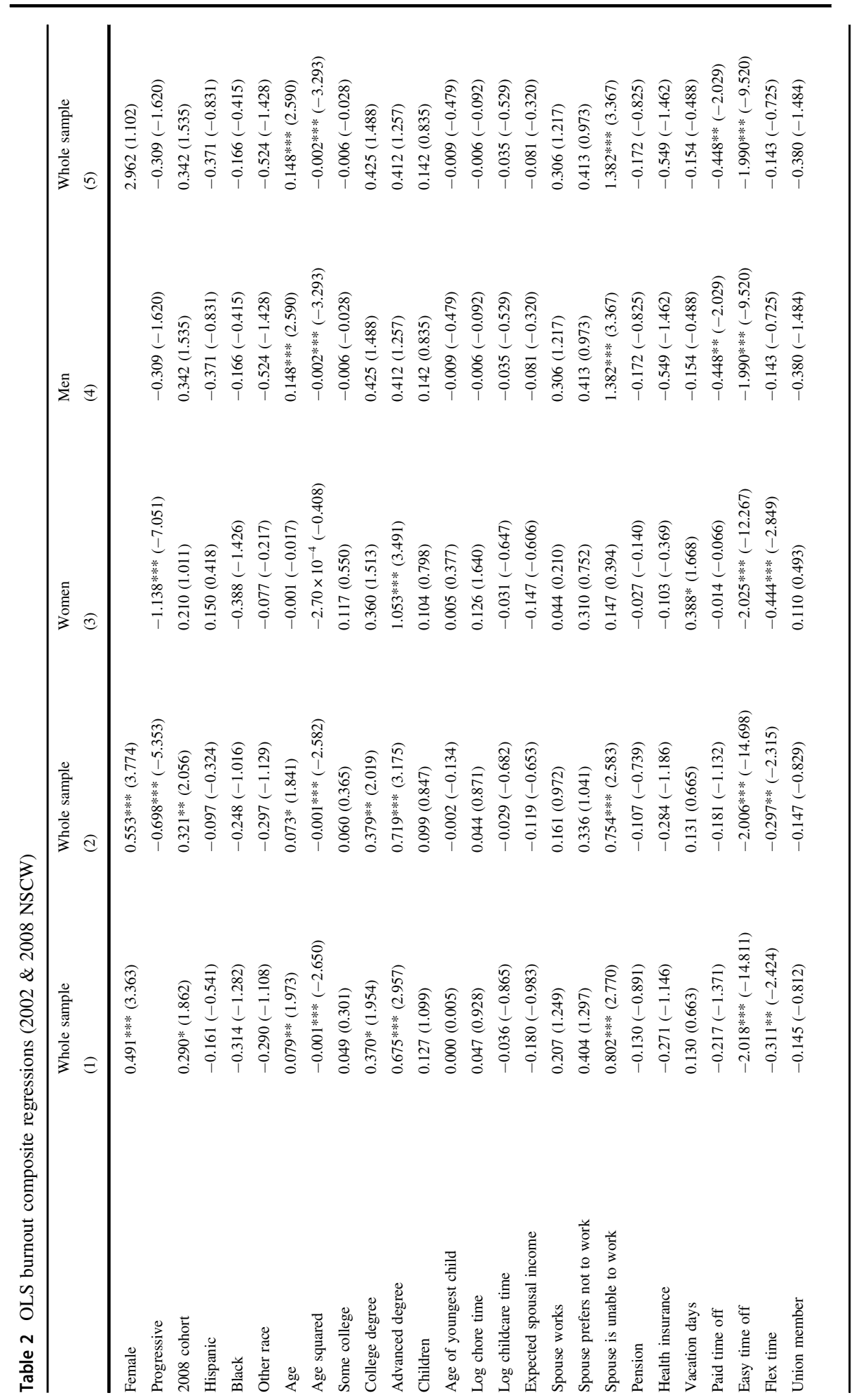




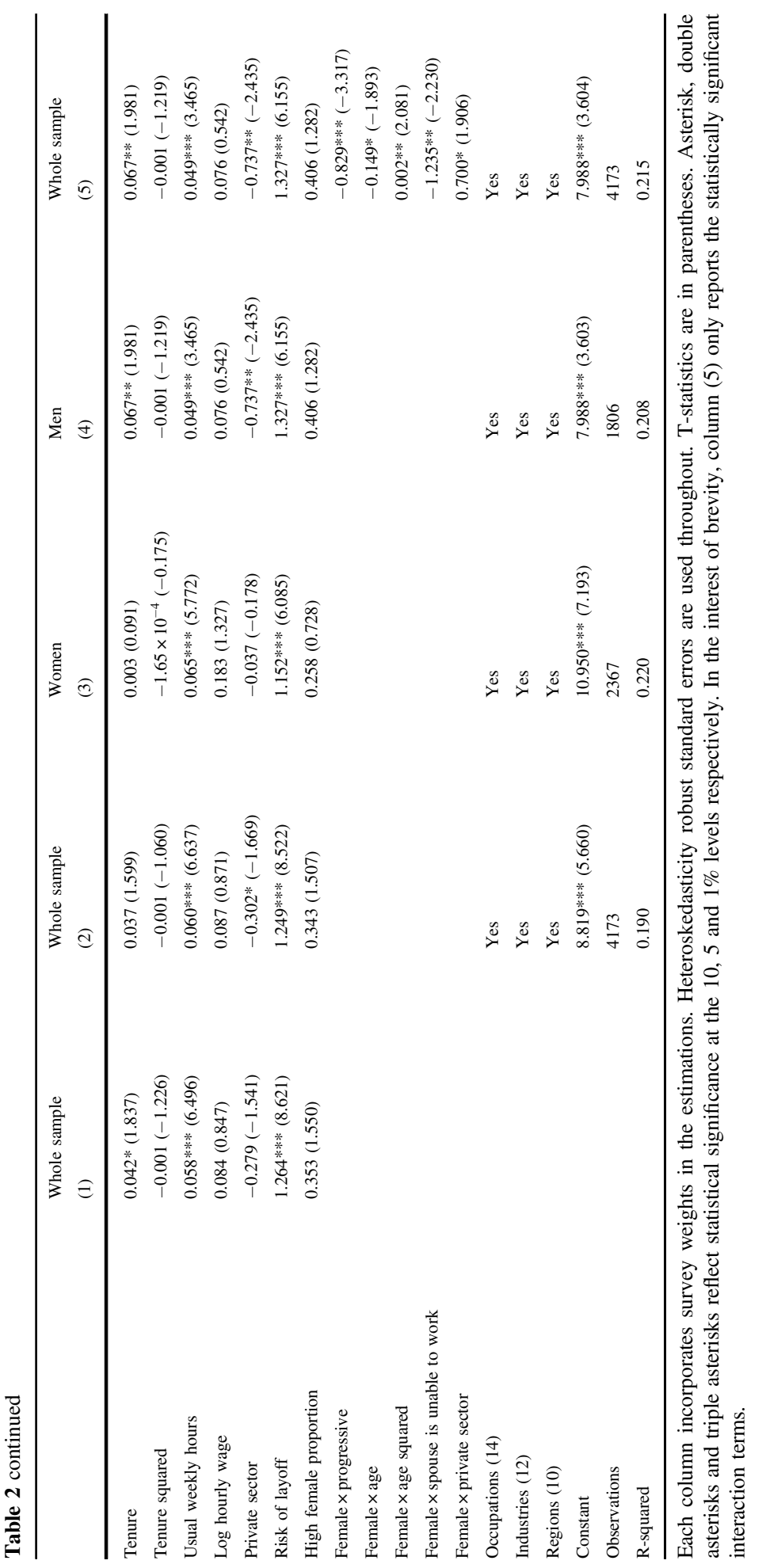


significantly and positively related to stress and mental health score. They find that workers with a college education or more have a higher MHS which means worse mental health than those with less than high school education. Thus, our results reflect what might have been inferred from the literature; education and burnout are positively correlated.

Table 2 column 1 also contain additional variables that could plausibly explain why women might be reporting greater burnout than men. We located some theoretically relevant variables in the NSCW data that could potentially explain the burnout. Among the variables included in column 1, we find that particular facets of jobs such as asking for time off easily when needed, asking for a flexible schedule, usual weekly work hours, risk of layoff and being the sole earner due to a spouse being unable to work are statistically significantly associated with self-reported burnout $^{13}$.

One remaining mechanism to explain the gender gap in job-related burnout may rely on differences by gender in job expectations or preferences. Namely, if expectations of work differ between men and women, then perhaps work-related burnout may differ as well and depend upon whether a worker's job meets those expectations. However, it is difficult to identify what people expect out of their work, or what priority level in their lives they feel paid work ought to be. We begin by coding workers as "progressive" versus "traditional" where the details of both groups are described in the previous section. These classifications provide clues informing us of the workers' job expectations and preferences. For instance, we might presume that workers we label as "progressive" might expect a job to play a more important part of their lives than those we label as "traditional". Table 2, column 2 presents results with this added variable. We hypothesize that including the progressive variable in the model may be a key factor in explaining the high level of burnout among females. Even though progressive individuals significantly report lower levels of burnout, the female coefficient is still positive and significant. To better understand the effect of being progressive between genders, we divided the whole sample into gender subgroups in columns 3 (women) and 4 (men). The negative and statistically significant relationship between being progressive and self-reported burnout in column 3 suggests that "progressive" women are far less likely to report burnout compared to "traditional" women. Male burnout seems not to be affected by ideological alignment (column 4) as the progressive coefficient is not statistically significant for this

\footnotetext{
13 The OLS results in Table 2 explain the variation in our composite measure of burnout that equally weighs respondents' perceptions of four components. Each component is a Likert style five category variable that is typically best-explained using a non-linear estimator such as ordered probit or logit. It is thus prudent to check the composite measure's robustness by leveraging the ordered categorical structure of each component burnout measure in non-linear estimations. We need to be certain that OLS and the equal weighting of each component in the composite measure are accurately reflecting the sign and significance of the true result. Appendix Table A presents results of ordered probit estimations of each component measure (which are described in Table 1) separately. Indeed, the sign and significance of the gender indicator's coefficient and marginal effect for each component reflect those of the composite measure in the Table 2 OLS estimations.
} 
group. Nevertheless, it is also worth noting that the progressive coefficient is negative for men as well though its magnitude is substantially smaller compared to women. One potential reason for this finding is that, despite the fact that women's labor force participation has steadily increased over the past few decades, society still largely attributes the position of primary breadwinner to men. As a result, both progressive and traditional men seem to place themselves as the family's central breadwinner and adjust their job expectations accordingly.

Relevant to the education discussion above, advanced degrees are only related to significantly greater burnout among women. Aging (at a decreasing rate), tenure at job and being the sole earner due to spouse being unable to work increase burnout among men while working in the private sector decreases male burnout. Whereas ease in asking time off, usual weekly work hours and risk of layoff matters for both men and women, only female burnout decreases with flexible working hours and only male burnout decreases with paid time off.

As the progressive variable seems to matter for women's self-reported job burnout (column 3), we decided to further explore the effect of being progressive. We interact each variable with the gender indicator in OLS estimates in order to determine whether women respond differently than men to each variable in their impact on burnout. We report only the significant interaction terms in column $5^{14}$. The disappearance of higher self-reported burnout among women is the most striking finding in column 5. The results show that self-reported burnout increases with age at a decreasing rate among men, whereas age is unrelated to burnout among women (the effect of an additional year of age on burnout for females is $0.148-0.149=0.001)$. We observe the same for spouse hardship. For men, having a spouse not working because of a hardship significantly increases burnout for those men, but among women, having a spouse not working due to hardship does not impact burnout at all (the effect of a spouse not working due to hardship on burnout for females is $1.382-1.235=0.147$ ). While this seems to be intriguing, we can only guess or speculate because we do not know the precise explanation behind it, as the data do not specify why the spouse cannot work. Men with working spouses may prioritize household earnings and status in order to maximize their utility. A working spouse helps to achieve these goals. A spouse who is willing but unable to work may have raised a man's aspirations for higher household earnings at one point, but now that the spouse cannot work, the probability of obtaining higher earnings and status compared to expectations has decreased, lowering utility and increasing pressure on the male to work harder to

\footnotetext{
${ }^{14}$ By inputting the interaction terms for men $=0$ and women $=1$, column 5 will provide the same coefficients as columns 3 and 4 . The base group in column 5 is "men" therefore, the coefficients for the variables in columns 4 and 5 are identical, with the exception of the interaction variables. For example, each additional year of age has a burnout effect of 0.148 for men and $0.148-0.149=-0.001$ for women, or a spouse not working due to difficulty has a burnout effect of 1.382 for men and $1.382-1.235=0.147$ for women. Column 5 contains coefficients from a wider range of groups compared to columns 3 and 4 . For example, we can only compare progressive and traditional women in column 3, and progressive and traditional men in column 4. Traditional women and progressive men, for example, can be compared in column 5 .
} 
Table 3 Burnout oaxaca-blinder decomposition

\begin{tabular}{llll}
\hline & $\begin{array}{l}\text { Gender gap } \\
(1)\end{array}$ & $\begin{array}{l}\text { Explained } \\
(2)\end{array}$ & $\begin{array}{l}\text { Unexplained } \\
(3)\end{array}$ \\
\hline Whole sample & $0.255^{*}(1.923)$ & $-0.297 * * *(-2.856)$ & $0.553^{* * *(3.801)}$ \\
Progressive & $0.051(0281)$ & $-0.293 *(-2.025)$ & $0.344 *(1.852)$ \\
Not progressive & $0.717 * *(3.785)$ & $-0.137(-0.855)$ & $0.854 * * *(3.904)$ \\
& Traditional-Progressive gap & Explained & Unexplained \\
Women $^{\mathrm{a}}$ & $1.081^{* * *(6.237)}$ & $-0.057(-0.619)$ & $1.138^{* * *(7.184)}$ \\
\hline
\end{tabular}

t-statistics are in parentheses; asterisk, double asterisks and triple asterisks reflect statistical significance at the 10,5 and $1 \%$ levels, respectively. We used the Oaxaca program with the pooled option (Jann, 2008) in Stata 16.0 for this analysis

${ }^{a}$ the gap is between progressive and non-progressive women. The gap in column (1) indicates that nonprogressive women exhibit 1.081 more burnout points than progressive women

make up the gap. This, however, seems irrelevant to women according to our results, as other considerations may take priority.

Employment in the private sector, on the other hand, significantly lowers burnout for men while having no significant effect on women. The progressive variable is the only one that draws distinction in terms of burnout between women and men as well as among women. Progressive men report a bit less burnout than traditional men (almost significant at the $10 \%$ level), but progressive women report far less burnout than traditional women and men. Thus, our results suggest that the progressive variable may be a key factor both between and within gender burnout differences.

In the interest of further understanding the gender gap in burnout, we utilize an Oaxaca-Blinder decomposition following Jann (2008) that breaks down the gender gap into two separate contributing components (Oaxaca, 1973; Blinder, 1973). First, an "explained effect" reflects the portion of the gender gap in burnout due to differences between genders in covariate levels. Second, an "unexplained effect" measures how much of the gender gap stems from differences between genders in coefficient estimates and the constant. Since the gap suggests men experience lower burnout than women, this method basically helps one to see if the difference will change if women shared the same covariate characteristics as men (explained) or the effect such covariates have on burnout (unexplained). The first three rows in Table 3 present three different decomposition results.

The first row in Table 3 decomposes the gender gap in burnout for the whole sample while rows two and three decompose the gap among separate sub-samples of the progressive and not progressive, respectively. First for the whole sample, column 1 shows the mean burnout score for women is a statistically significant 0.255 points higher than men's mean burnout score. Columns 2 and 3 highlight the decomposed effects. The unexplained portion of the gap, presented in column 3, is larger and more than offsets the explained effect, presented in column 2. This implies that gender differences in the impacts of the covariates on burnout-the coefficient estimates - are the primary drivers of the gap in burnout, rather than the attribute/ covariate levels. Thus, column 3 illustrates that if women's coefficient estimates were 
similar to men's, the gender disparity in burnout would be minimized, if not abolished.

The progressive sub-sample decompositions in rows 2 and 3 are quite interesting. The progressive worker decomposition mirrors the whole sample's explained effect alongside a somewhat smaller unexplained effect, leading to an overall insignificant and very small gender gap in burnout. Here, the gap-exacerbating effects of male covariate levels on female burnout are almost perfectly offset by the gap-mitigating effects of male coefficient estimates. Thus, on net there is no gender gap in burnout among workers with progressive attitudes. However, the sub-sample of nonprogressive workers portrays an entirely different situation. The gender gap in burnout is enormous, nearly three times the size as in the whole sample. Moreover, covariate levels explain an insignificant and small portion of the gap, meaning the gender gap in burnout would not be affected if traditional women, for instance, worked the same hours as traditional men. Instead, it seems the gender gap is made up entirely of the unexplained portion, and that non-progressive women's burnout would be equivalent to men's if they shared men's coefficient estimates. For these workers, the observable characteristic levels do not contribute to the gender gap in burnout. Rather, it is the difference in the effects that these covariates have between men and women that seems to drive the gap in burnout. Finally, the fourth row in Table 3 decomposes the gap in burnout for women among separate subsamples of progressive and not progressive. The gap in column (1) indicates that nonprogressive women exhibit 1.081 more burnout points than progressive women, and this is entirely explained by the differences between progressive and non-progressive women in how the covariates effect burnout, and not in the covariates' levels.

Appendix table B offers robustness checks by first examining whether the results for the composite measure in Table 2 are also seen in the burnout component estimations. They are very similar except for one difference: "progressive" men also report having more energy than "traditional" men (column 1). Appendix table B also presents estimates incorporating different progressive identifications in columns 5 and 6. Measurement error is a possible problem in identifying ideologies; thus, we utilize other combinations and degrees of agreement and disagreement with these questions in order to be certain our results are not spuriously related to only one form of the measure. Our progressive indicator thus far does not entirely exclude all those who may moderately disagree with the progressive statement or moderately agree with the traditional statement. Accordingly, we present estimates instead incorporating an indicator of more progressive workers that reduces the proportion identified as progressive down to 41 from $58 \%$. Third we introduce a most progressive indicator comprising only $25 \%$ of workers; only including those who both strongly agree with the progressive statement and strongly disagree with the traditional statement. These indicators that isolate even more ideologically progressive workers show even less reported burnout among women the more progressive they get.

It seems from our analysis that gender-role perceptions may play a large part in understanding why women report more job-related burnout than men. Only traditional women, or those more likely to feel women are better suited to taking care of domestic work and correspondingly maintain good relationships with children, are more likely to report job-related burnout than men. As an extension 
though, we sought to examine whether other differences exist in how ideology might affect burnout. Appendix table $\mathrm{C}$ presents sub-sample estimates by progressive status. Among "traditional" workers, married workers with spouses unable to work report more burnout. Among "progressive" workers, only wages seem to elicit a different effect. Higher wages correspond with more burnout only among progressive workers. These other effects may lend support for our hypothesis that work expectations can influence perceived burnout. Married "traditional" workers with spouses unable to work and highly paid "progressive" workers alike may have expectations or preferences that are unrealized by their jobs and consequently report more burnout.

\section{Conclusion}

The literature on job-related burnout is vast. Yet, the majority of studies depend on limited sample sizes, specific professions, and population subsets. Instead, we use data from a broad, nationally representative US survey of employees from a wide range of occupations and industries. The data are rich in demographic, career, and personality characteristics, allowing us to distinguish job-related burnout incidences, potentially causal factors connected to burnout, and insights on gender dynamics in the labor market and society. We hypothesize that gender differences in job expectations and preferences, which have previously been overlooked in the literature, can play a role in assessing job-related burnout.

First, we find that women report more job-related burnout than men. The effect is significant and the size is substantial. Second, theoretically linked variables that might explain the gender gap in job-related burnout fail to do so. Specifically, women do not report more burnout due to working harder at home, spending more time on childcare, fearing job loss, working in jobs not equally represented by women, or finding it hard to advance in the job. Typical demographic and job characteristics such as race, age, education, marital and parenthood status, fringe benefits, tenure, hours worked or wages also do not explain away women's propensity to report more job-related burnout than men. Instead, we find that "progressive" women report job-related burnout at a rate equivalent to that of men, whereas "traditional" women report substantially more jobrelated burnout. We hypothesize that working for pay is not aligned with "traditional" women's expectations or preferences, and they report more burnout as a result. By contrast, "progressive" women may expect and prefer that working for pay be a significant part of their lives. Consequently, "progressive" women that work for pay report less job-related burnout than "traditional" women that work for pay.

Our study has a number of limitations; thus, our results should be assessed and interpreted with caution. First, this study proposes that ideology (perception) about the gender roles of women explains gender differences in burnout. However, factors related to the formation of gender perceptions and not controlled for in our study may also link gender differences to job burnout. For instance, we cannot directly control for the degree of support from family and friends in successfully completing both unpaid caregiving and paid work. Thus, we cannot perfectly identify whether a "traditional" woman has an equivalent network of support as a "progressive" woman. Second, although the literature universally uses subjective measures as proxies for 
job burnout, additional objective measures of burnout would provide more robust results. Third, our data are only cross-sectional and therefore do not allow us to control for unobservable and time invariant factors that very well may be important determinants of the gender difference in burnout. Replication of our findings with longitudinal data would help moderate the related bias. Fourth, although we use a rich data set formed by nationally representative and heterogeneous surveys containing workers' sentiment across two different business cycles (an expansion versus contraction), our sample is limited to workers in the United States. While developed countries share common characteristics in their market and institutional conditions, individual cultural and environmental factors may impact the experience of job burnout. Thus, our results may not be externally valid outside of the US. Finally, we would like to note that there might be a concern for a potential selection bias for our estimations due to those who may have lost or quit their job due to extreme burnout and the resulting lower performance. Nevertheless, we are unable to determine the extent of the impact of such potential bias in our estimates because we have no means of knowing what percentage of the workers lost/quit their jobs due to serious burnout and associated performance problems. Although there are solutions to this issue, they would necessitate knowledge about those who are not employed. Unfortunately, the NSCW dataset only covers people who have a paying job or self-employed, thus it is only a representative sample of employed workers at the time of the survey. Furthermore, as in any other survey-based examinations, non-response bias and measurement error are concerns in our study. Nevertheless, our study provides openings for further research to examine and expand upon our findings.

Funding This research is funded by the American University of Sharjah (grant number: FRG20-SB127).

\section{Compliance with ethical standards}

Conflict of interest The authors declare no competing interests.

Publisher's note Springer Nature remains neutral with regard to jurisdictional claims in published maps and institutional affiliations.

\section{Appendix Table A: Ordered probit burnout components}

\begin{tabular}{lllll}
\hline & $\begin{array}{l}\text { No energy } \\
(1)\end{array}$ & $\begin{array}{l}\text { Work disrupts } \\
(2)\end{array}$ & $\begin{array}{l}\text { Overwhelmed } \\
(3)\end{array}$ & $\begin{array}{l}\text { Bad mood } \\
(4)\end{array}$ \\
\hline Female & $0.129 * * *(2639)$ & $0.124 * *(2.478)$ & $\begin{array}{l}0.155^{* * *}(3.269) \\
\{0.038\}\end{array}$ & $\begin{array}{l}0.125^{* *}(2.530) \\
\{0.014\}\end{array}$ \\
& $\{0.015\}$ & $\{0.014\}$ & 4173 & 4173 \\
\hline
\end{tabular}

All Table 2 Column 1 covariates are also included in each column's estimations. Each column incorporates survey weights in the estimations. Heteroskedasticity robust standard errors are used throughout. T-statistics are in parentheses

Asterisk, double asterisks and triple asterisks reflect statistical significance at the 10, 5 and $1 \%$ levels respectively. Marginal effects are in brackets 
7 Appendix Table B: OLS burnout regressions (2002 \& 2008 NSCW)

\begin{tabular}{|c|c|c|c|c|c|c|}
\hline & \multirow{2}{*}{$\begin{array}{l}\text { No energy } \\
\text { (1) }\end{array}$} & \multirow{2}{*}{$\begin{array}{l}\text { Work } \\
\text { disrupts } \\
\text { (2) }\end{array}$} & \multirow{2}{*}{$\begin{array}{l}\text { Over- } \\
\text { whelmed } \\
(3)\end{array}$} & \multirow{2}{*}{$\begin{array}{l}\text { Bad mood } \\
\text { (4) }\end{array}$} & \multicolumn{2}{|c|}{ Burnout composite } \\
\hline & & & & & (5) & (6) \\
\hline Female & $\begin{array}{l}-0.011 \\
(-0.014)\end{array}$ & $\begin{array}{l}1.999 * * \\
(2.400)\end{array}$ & $\begin{array}{l}0.130 \\
(0.123)\end{array}$ & $\begin{array}{l}0.845 \\
(1.072)\end{array}$ & $\begin{array}{l}2.984 \\
(1.107)\end{array}$ & $\begin{array}{l}3.058 \\
(1.147)\end{array}$ \\
\hline Progressive & $\begin{array}{l}-0.184 * * * \\
(-2.814)\end{array}$ & $\begin{array}{l}-0.052 \\
(-0.798)\end{array}$ & $\begin{array}{l}-0.017 \\
(-0.271)\end{array}$ & $\begin{array}{l}-0.056 \\
(-0.940)\end{array}$ & & \\
\hline $\begin{array}{l}\text { Female * } \\
\text { progressive }\end{array}$ & $\begin{array}{l}-0.144^{*} \\
(-1.708)\end{array}$ & $\begin{array}{l}-0.244 * * * \\
(-2.877)\end{array}$ & $\begin{array}{l}-0.214 * * \\
(-2.416)\end{array}$ & $\begin{array}{l}-0.228 * * * \\
(-2.878)\end{array}$ & & \\
\hline $\begin{array}{l}\text { More } \\
\text { progressive }\end{array}$ & & & & & $\begin{array}{l}-0.234 \\
(-1.145)\end{array}$ & \\
\hline $\begin{array}{l}\text { Female } * \text { more } \\
\text { progressive }\end{array}$ & & & & & $\begin{array}{l}-0.869 * * * \\
(-3.361)\end{array}$ & \\
\hline Most progressive & & & & & & $\begin{array}{l}-0.151 \\
(-0.588)\end{array}$ \\
\hline $\begin{array}{l}\text { Female } * \text { most } \\
\text { progressive }\end{array}$ & & & & & & $\begin{array}{l}-0.990 \text { *** } \\
(-3.220)\end{array}$ \\
\hline Constant & $\begin{array}{l}2.093 * * * \\
(3.332)\end{array}$ & $\begin{array}{l}1.233 * * \\
(2.028)\end{array}$ & $\begin{array}{l}2.533 * * * \\
(2.991)\end{array}$ & $\begin{array}{l}2.129 * * * \\
(3.798)\end{array}$ & $\begin{array}{l}7.822 * * * \\
(3.530)\end{array}$ & $\begin{array}{l}7.665^{* * * *} \\
(3.518)\end{array}$ \\
\hline Observations & 4173 & 4173 & 4173 & 4173 & 4173 & 4173 \\
\hline R-squared & 0.169 & 0.156 & 0.139 & 0.160 & 0.214 & 0.213 \\
\hline
\end{tabular}

All Table 2 Column 4 covariates and interactions are also included in each column's estimations. Each column incorporates survey weights in the estimations. Heteroskedasticity robust standard errors are used throughout. T-statistics are in parentheses

Asterisk, double asterisks and triple asterisks reflect statistical significance at the 10,5 and $1 \%$ levels respectively

\section{Appendix Table C: OLS burnout composite regressions; progressive sub-samples}

\begin{tabular}{|c|c|c|c|c|c|c|}
\hline & $\begin{array}{l}\text { Progressive } \\
\text { (1) }\end{array}$ & $\begin{array}{l}\text { Not } \\
\text { progressive } \\
\text { (2) }\end{array}$ & $\begin{array}{l}\text { More } \\
\text { progressive } \\
\text { (3) }\end{array}$ & $\begin{array}{l}\text { Not more } \\
\text { progressive } \\
\text { (4) }\end{array}$ & $\begin{array}{l}\text { Most } \\
\text { progressive } \\
\text { (5) }\end{array}$ & $\begin{array}{l}\text { Not most } \\
\text { progressive } \\
\text { (6) }\end{array}$ \\
\hline Female & $\begin{array}{l}0.344 * \\
(1.853)\end{array}$ & $\begin{array}{l}0.854^{* * * *} \\
(3.785)\end{array}$ & $0.074(0.339)$ & $\begin{array}{l}0.883 * * * \\
(4.490)\end{array}$ & $\begin{array}{l}-0.038 \\
(-0.141)\end{array}$ & $\begin{array}{l}0.827 * * * \\
(4.874)\end{array}$ \\
\hline 2008 cohort & $\begin{array}{l}0.243 \\
(1.148)\end{array}$ & $\begin{array}{l}0.312 \\
(1.394)\end{array}$ & 0.277 (1.099) & $\begin{array}{l}0.327^{*} \\
(1.695)\end{array}$ & $\begin{array}{l}-0.107 \\
(-0.327)\end{array}$ & $\begin{array}{l}0.411 * * \\
(2.441)\end{array}$ \\
\hline Hispanic & $\begin{array}{l}-0.083 \\
(-0.217)\end{array}$ & $\begin{array}{l}-0.056 \\
(-0.143)\end{array}$ & $\begin{array}{l}-0.664 * \\
(-1.668)\end{array}$ & $\begin{array}{l}0.139 \\
(0.359)\end{array}$ & $\begin{array}{l}-1.360 * * * \\
(-2.953)\end{array}$ & $\begin{array}{l}0.313 \\
(0.925)\end{array}$ \\
\hline Black & $\begin{array}{l}-0.370 \\
(-1.234)\end{array}$ & $\begin{array}{l}-0.298 \\
(-0.792)\end{array}$ & $\begin{array}{l}-0.270 \\
(-0.769)\end{array}$ & $\begin{array}{l}-0.450 \\
(-1.483)\end{array}$ & $\begin{array}{l}-0.330 \\
(-0.760)\end{array}$ & $\begin{array}{l}-0.440 \\
(-1.634)\end{array}$ \\
\hline Other race & $\begin{array}{l}-0.179 \\
(-0.507)\end{array}$ & $\begin{array}{l}-0.444 \\
(-1.188)\end{array}$ & $0.278(0.672)$ & $\begin{array}{l}-0.603^{*} \\
(-1.867)\end{array}$ & $\begin{array}{l}0.406 \\
(0.816)\end{array}$ & $\begin{array}{l}-0.424 \\
(-1.446)\end{array}$ \\
\hline
\end{tabular}


Table continued

\begin{tabular}{|c|c|c|c|c|c|c|}
\hline & $\begin{array}{l}\text { Progressive } \\
\text { (1) }\end{array}$ & $\begin{array}{l}\text { Not } \\
\text { progressive } \\
\text { (2) }\end{array}$ & $\begin{array}{l}\text { More } \\
\text { progressive } \\
\text { (3) }\end{array}$ & $\begin{array}{l}\text { Not more } \\
\text { progressive } \\
\text { (4) }\end{array}$ & $\begin{array}{l}\text { Most } \\
\text { progressive } \\
\text { (5) }\end{array}$ & $\begin{array}{l}\text { Not most } \\
\text { progressive } \\
\text { (6) }\end{array}$ \\
\hline Age & $\begin{array}{l}0.022 \\
(0.405)\end{array}$ & $\begin{array}{l}0.177 * * * \\
(3.165)\end{array}$ & $0.079(1.252)$ & $\begin{array}{l}0.092 * \\
(1.843)\end{array}$ & $\begin{array}{l}0.164 * * \\
(2.077)\end{array}$ & $\begin{array}{l}0.055 \\
(1.238)\end{array}$ \\
\hline Age squared & $\begin{array}{l}-0.001 \\
(-0.947)\end{array}$ & $\begin{array}{l}-0.002 * * * \\
(-3.670)\end{array}$ & $\begin{array}{l}-0.001^{*} \\
(-1.730)\end{array}$ & $\begin{array}{l}-0.001 * * \\
(-2.416)\end{array}$ & $\begin{array}{l}-0.002 * * \\
(-2.382)\end{array}$ & $\begin{array}{l}-0.001^{*} \\
(-1.956)\end{array}$ \\
\hline Some college & $\begin{array}{l}0.158 \\
(0.722)\end{array}$ & $\begin{array}{l}-0.017 \\
(-0.074)\end{array}$ & $\begin{array}{l}-0.077 \\
(-0.298)\end{array}$ & $\begin{array}{l}0.201 \\
(1.013)\end{array}$ & $\begin{array}{l}-0.169 \\
(-0.481)\end{array}$ & $\begin{array}{l}0.133 \\
(0.750)\end{array}$ \\
\hline College degree & $\begin{array}{l}0.670 * * * \\
(2.695)\end{array}$ & $\begin{array}{l}0.069 \\
(0.247)\end{array}$ & $0.482(1.631)$ & $\begin{array}{l}0.392 \\
(1.632)\end{array}$ & $\begin{array}{l}-0.029 \\
(-0.076)\end{array}$ & $\begin{array}{l}0.531 * * \\
(2.493)\end{array}$ \\
\hline Advanced degree & $\begin{array}{l}0.981 * * * \\
(3.271)\end{array}$ & $\begin{array}{l}0.317 \\
(0.962)\end{array}$ & $\begin{array}{l}0.821 * * \\
(2.400)\end{array}$ & $\begin{array}{l}0.705 * * \\
(2.399)\end{array}$ & $\begin{array}{l}0.267 \\
(0.587)\end{array}$ & $\begin{array}{l}0.885 * * * \\
(3.442)\end{array}$ \\
\hline Children & $\begin{array}{l}0.096 \\
(0.548)\end{array}$ & $\begin{array}{l}0.106 \\
(0.825)\end{array}$ & $0.151(0.612)$ & $\begin{array}{l}0.095 \\
(0.831)\end{array}$ & $\begin{array}{l}0.200 \\
(0.631)\end{array}$ & $\begin{array}{l}0.077 \\
(0.712)\end{array}$ \\
\hline Age of youngest & $\begin{array}{l}0.008 \\
(0.479)\end{array}$ & $\begin{array}{l}-0.011 \\
(-0.648)\end{array}$ & $0.012(0.649)$ & $\begin{array}{l}-0.007 \\
(-0.504)\end{array}$ & $\begin{array}{l}0.008 \\
(0.331)\end{array}$ & $\begin{array}{l}-0.002 \\
(-0.169)\end{array}$ \\
\hline Log chore time & $\begin{array}{l}0.084 \\
(1.302)\end{array}$ & $\begin{array}{l}-0.004 \\
(-0.053)\end{array}$ & $0.093(1.192)$ & $\begin{array}{l}0.022 \\
(0.355)\end{array}$ & $\begin{array}{l}0.204 * \\
(1.929)\end{array}$ & $\begin{array}{l}0.003 \\
(0.060)\end{array}$ \\
\hline $\begin{array}{l}\text { Log } \\
\text { childcare time }\end{array}$ & $\begin{array}{l}-0.006 \\
(-0.100)\end{array}$ & $\begin{array}{l}-0.056 \\
(-1.057)\end{array}$ & $\begin{array}{l}-0.032 \\
(-0.406)\end{array}$ & $\begin{array}{l}-0.041 \\
(-0.900)\end{array}$ & $\begin{array}{l}-0.082 \\
(-0.823)\end{array}$ & $\begin{array}{l}-0.015 \\
(-0.360)\end{array}$ \\
\hline Exp. spousal inc. & $\begin{array}{l}-0.122 \\
(-0.580)\end{array}$ & $\begin{array}{l}-0.217 \\
(-0.566)\end{array}$ & $\begin{array}{l}-0.120 \\
(-0.571)\end{array}$ & $\begin{array}{l}-0.253 \\
(-0.838)\end{array}$ & $\begin{array}{l}0.025 \\
(0.112)\end{array}$ & $\begin{array}{l}-0.283 \\
(-1.097)\end{array}$ \\
\hline Spouse works & $\begin{array}{l}0.018 \\
(0.088)\end{array}$ & $\begin{array}{l}0.330 \\
(1.257)\end{array}$ & $0.055(0.236)$ & $\begin{array}{l}0.228 \\
(1.013)\end{array}$ & $\begin{array}{l}-0.080 \\
(-0.278)\end{array}$ & $\begin{array}{l}0.238 \\
(1.212)\end{array}$ \\
\hline $\begin{array}{l}\text { Spouse } \\
\text { prefers not }\end{array}$ & $\begin{array}{l}0.407 \\
(0.775)\end{array}$ & $\begin{array}{l}0.322 \\
(0.992)\end{array}$ & $0.493(1.202)$ & $\begin{array}{l}0.296 \\
(0.820)\end{array}$ & $\begin{array}{l}0.749 \\
(1.373)\end{array}$ & $\begin{array}{l}0.316 \\
(0.940)\end{array}$ \\
\hline Spouse is unable & $\begin{array}{l}0.533 \\
(1.237)\end{array}$ & $\begin{array}{l}0.841 * * \\
(2.391)\end{array}$ & $0.235(0.467)$ & $\begin{array}{l}0.945^{* * * *} \\
(2.765)\end{array}$ & $\begin{array}{l}0.052 \\
(0.078)\end{array}$ & $\begin{array}{l}0.975 * * * \\
(3.210)\end{array}$ \\
\hline Pension & $\begin{array}{l}-0.153 \\
(-0.792)\end{array}$ & $\begin{array}{l}-0.054 \\
(-0.257)\end{array}$ & $\begin{array}{l}-0.182 \\
(-0.801)\end{array}$ & $\begin{array}{l}-0.101 \\
(-0.558)\end{array}$ & $\begin{array}{l}-0.027 \\
(-0.089)\end{array}$ & $\begin{array}{l}-0.155 \\
(-0.974)\end{array}$ \\
\hline Health insurance & $\begin{array}{l}-0.812 * * \\
(-2.557)\end{array}$ & $\begin{array}{l}0.370 \\
(1.089)\end{array}$ & $\begin{array}{l}-0.368 \\
(-1.010)\end{array}$ & $\begin{array}{l}-0.167 \\
(-0.584)\end{array}$ & $\begin{array}{l}-0.541 \\
(-1.154)\end{array}$ & $\begin{array}{l}-0.158 \\
(-0.614)\end{array}$ \\
\hline Vacation days & $\begin{array}{l}0.066 \\
(0.251)\end{array}$ & $\begin{array}{l}0.235 \\
(0.853)\end{array}$ & $\begin{array}{l}-0.051 \\
(-0.165)\end{array}$ & $\begin{array}{l}0.259 \\
(1.062)\end{array}$ & $\begin{array}{l}-0.446 \\
(-1.110)\end{array}$ & $\begin{array}{l}0.325 \\
(1.506)\end{array}$ \\
\hline Paid time off & $\begin{array}{l}-0.332 \\
(-1.576)\end{array}$ & $\begin{array}{l}0.009 \\
(0.041)\end{array}$ & $\begin{array}{l}-0.181 \\
(-0.744)\end{array}$ & $\begin{array}{l}-0.172 \\
(-0.843)\end{array}$ & $\begin{array}{l}0.063 \\
(0.194)\end{array}$ & $\begin{array}{l}-0.255 \\
(-1.449)\end{array}$ \\
\hline Easy time off & $\begin{array}{l}-1.810 * * * \\
(-9.957)\end{array}$ & $\begin{array}{l}-2.119 * * * \\
(-10.885)\end{array}$ & $\begin{array}{l}-1.935^{* * * *} \\
(-9.445)\end{array}$ & $\begin{array}{l}-1.981 \text { **** } \\
(-11.241)\end{array}$ & $\begin{array}{l}-2.196 * * * \\
(-8.597)\end{array}$ & $\begin{array}{l}-1.918^{* * * *} \\
(-12.448)\end{array}$ \\
\hline Flex time & $\begin{array}{l}-0.319^{*} \\
(-1.932)\end{array}$ & $\begin{array}{l}-0.209 \\
(-1.110)\end{array}$ & $\begin{array}{l}-0.292 \\
(-1.528)\end{array}$ & $\begin{array}{l}-0.235 \\
(-1.449)\end{array}$ & $\begin{array}{l}-0.552 * * \\
(-2.268)\end{array}$ & $\begin{array}{l}-0.265^{*} \\
(-1.862)\end{array}$ \\
\hline Union member & $\begin{array}{l}-0.197 \\
(-0.828)\end{array}$ & $\begin{array}{l}0.044 \\
(0.176)\end{array}$ & $\begin{array}{l}-0.248 \\
(-0.887)\end{array}$ & $\begin{array}{l}-0.075 \\
(-0.337)\end{array}$ & $\begin{array}{l}-0.606 \\
(-1.573)\end{array}$ & $\begin{array}{l}0.020 \\
(0.104)\end{array}$ \\
\hline Tenure & $\begin{array}{l}0.054 * \\
(1.660)\end{array}$ & $\begin{array}{l}0.008 \\
(0.262)\end{array}$ & $0.030(0.752)$ & $\begin{array}{l}0.038 \\
(1.385)\end{array}$ & $\begin{array}{l}0.064 \\
(1.231)\end{array}$ & $\begin{array}{l}0.038 \\
(1.527)\end{array}$ \\
\hline Tenure squared & $\begin{array}{l}-0.001 \\
(-1.255)\end{array}$ & $\begin{array}{l}4.45 \times 10^{-5} \\
(0.044)\end{array}$ & $\begin{array}{l}-3.98 \times 10^{-4} \\
(-0.312)\end{array}$ & $\begin{array}{l}-0.001 \\
(-0.981)\end{array}$ & $\begin{array}{l}-0.002 \\
(-1.071)\end{array}$ & $\begin{array}{l}-0.001 \\
(-0.864)\end{array}$ \\
\hline
\end{tabular}


Table continued

\begin{tabular}{|c|c|c|c|c|c|c|}
\hline & $\begin{array}{l}\text { Progressive } \\
\text { (1) }\end{array}$ & $\begin{array}{l}\text { Not } \\
\text { progressive } \\
\text { (2) }\end{array}$ & $\begin{array}{l}\text { More } \\
\text { progressive } \\
\text { (3) }\end{array}$ & $\begin{array}{l}\text { Not more } \\
\text { progressive } \\
\text { (4) }\end{array}$ & $\begin{array}{l}\text { Most } \\
\text { progressive } \\
\text { (5) }\end{array}$ & $\begin{array}{l}\text { Not most } \\
\text { progressive } \\
(6)\end{array}$ \\
\hline $\begin{array}{l}\text { Usual } \\
\text { weekly hours }\end{array}$ & $\begin{array}{l}0.071 * * * \\
(5.939)\end{array}$ & $\begin{array}{l}0.052^{* * * *} \\
(3.859)\end{array}$ & $\begin{array}{l}0.064 * * * \\
(4.880)\end{array}$ & $\begin{array}{l}0.054 * * * \\
(4.692)\end{array}$ & $\begin{array}{l}0.060 * * * \\
(3.309)\end{array}$ & $\begin{array}{l}0.057 * * * \\
(5.694)\end{array}$ \\
\hline Log hourly wage & $\begin{array}{l}0.246^{*} \\
(1.853)\end{array}$ & $\begin{array}{l}-0.097 \\
(-0.681)\end{array}$ & $\begin{array}{l}0.268 * \\
(1.840)\end{array}$ & $\begin{array}{l}-0.049 \\
(-0.364)\end{array}$ & $\begin{array}{l}0.377 * \\
(1.747)\end{array}$ & $\begin{array}{l}0.011 \\
(0.098)\end{array}$ \\
\hline Private sector & $\begin{array}{l}-0.393 \\
(-1.575)\end{array}$ & $\begin{array}{l}-0.162 \\
(-0.653)\end{array}$ & $\begin{array}{l}-0.724 * * \\
(-2.358)\end{array}$ & $\begin{array}{l}-0.006 \\
(-0.029)\end{array}$ & $\begin{array}{l}-0.854 * * \\
(-2.137)\end{array}$ & $\begin{array}{l}-0.114 \\
(-0.602)\end{array}$ \\
\hline Risk of layoff & $\begin{array}{l}1.277 * * * \\
(6.446)\end{array}$ & $\begin{array}{l}1.156^{* * * *} \\
(5.613)\end{array}$ & $\begin{array}{l}1.283 * * * \\
(5.724)\end{array}$ & $\begin{array}{l}1.213 * * * \\
(6.523)\end{array}$ & $\begin{array}{l}1.337 * * * \\
(4.647)\end{array}$ & $\begin{array}{l}1.208 * * * \\
(7.330)\end{array}$ \\
\hline $\begin{array}{l}\text { High } \\
\text { female prop. }\end{array}$ & $\begin{array}{l}0.174 \\
(0.600)\end{array}$ & $\begin{array}{l}0.564 \\
(1.559)\end{array}$ & $0.018(0.056)$ & $\begin{array}{l}0.605^{*} \\
(1.907)\end{array}$ & $\begin{array}{l}-0.182 \\
(-0.469)\end{array}$ & $\begin{array}{l}0.467 * \\
(1.717)\end{array}$ \\
\hline Occupations (14) & Yes & Yes & Yes & Yes & Yes & Yes \\
\hline Industries (12) & Yes & Yes & Yes & Yes & Yes & Yes \\
\hline Regions (10) & Yes & Yes & Yes & Yes & Yes & Yes \\
\hline Constant & $\begin{array}{l}8.773 * * * \\
(3.958)\end{array}$ & $\begin{array}{l}6.212 * * * \\
(3.404)\end{array}$ & $\begin{array}{l}8.084 * * * \\
(3.063)\end{array}$ & $\begin{array}{l}7.768 * * * \\
(4.985)\end{array}$ & $\begin{array}{l}3.655 \\
(1.353)\end{array}$ & $\begin{array}{l}9.602 * * * \\
(6.027)\end{array}$ \\
\hline Observations & 2428 & 1745 & 1729 & 2444 & 1037 & 3136 \\
\hline R-squared & 0.185 & 0.228 & 0.217 & 0.196 & 0.256 & 0.189 \\
\hline
\end{tabular}

The groups labeled "Not" in the above categories reflect the portion of the sample that does not belong to that category. The "Not more progressive" segment, for example, represents the portion of the sample that is not "more progressive". Each column incorporates survey weights in the estimations. Heteroskedasticity robust standard errors are used throughout. T-statistics are in parentheses

Asterisk, double asterisks and triple asterisks reflect statistical significance at the 10, 5 and $1 \%$ levels respectively

\section{References}

Ahola, K., Honkonen, T., Isometsä, E., Kalimo, R., Nykyri, E., \& Aromaa, A. (2005). The relationship between job-related burnout and depressive disorders-Results from the Finnish Health 2000 Study. Journal of Affective Disorders, 88, 55-62.

Ai, C., \& Norton, E. (2003). Interaction terms in logit and probit models. Economics Letters, 80(1), $123-129$.

Allen, T. D., Herts, D. E. L., Bruck, C. S., \& Sutton, M. (2000). Consequences associated with work-tofamily conflict: a review and agenda for future research. Journal of Occupational Health Psychology, 5, 278-308.

Antoniou, A. S., Polychroni, F., \& Vlachakis, A. N. (2006). Gender and age differences in occupational stress and professional burnout between primary and high school teachers in Greece. Journal of Managerial Psychology, 21, 682-690.

Bacharach, S. B., Bamberger, P., \& Conley, S. (1991). Work-home conflict among nurses and engineers: Mediating the impact of role stress on burnout and satisfaction at work. Journal of organizational Behavior, 12(1), 39-53.

Beauregard, T. A. (2011). Direct and indirect links between organizational work-home culture and employee wellbeing. British Journal of Management, 22, 218-237.

Bem, S. (1974). The measurement of psychological androgyny. Journal of Consulting and Clinical Psychology, 42(2), 155-162.

Benbow, S. M., \& Jolley, D. J. (2002). Burnout and stress amongst old age psychiatrists. International Journal of Geriatric Psychiatry, 17, 710-714. 
Blinder, A. S. (1973). Wage discrimination: reduced form and structural estimates. Journal of Human resources, 8(4), 436-455.

Brake, T. H., Bloemendal, E., \& Hoogstraten, J. (2003). Gender differences in burnout among Dutch dentists. Community Dent Oral Epidemiology, 31, 321-327.

Bureau of Labor Statistics (BLS), Families with own children: Employment status of parents by age of youngest child and family type, 2016-2017 annual averages (U.S. Department of Labor, 2017).

Carlson, D. S., Grzywacz, J. G., \& Zivnuska, S. (2009). Is work-family balance more than conflict and enrichment? Human relations, 62(10), 1459-1486.

Cha, Y., \& Thébaud, S. (2009). Labor markets, breadwinning, and beliefs: How economic context shapes men's gender ideology. Gender \& Society, 23(2), 215-243.

Cheng, Z., Mendolia, S., Paloyo, A. R., Savage, D. A., \& Tani, M. (2021). Working parents, financial insecurity, and childcare: mental health in the time of COVID-19 in the UK. Review of Economics of the Household, 19(1), 123-144.

Cook, H., MacKenzie, R., \& Forde, C. (2016). HRM and performance: the vulnerability of soft HRM practices during recession and retrenchment. Human Resource Management Journal, 26(4), 557-571.

Croda, E., \& Grossbard, S. (2021). Women pay the price of COVID-19 more than men. Review of Economics of the Household, 19(1), 1-9.

David, D. S., \& Brannon, R. (Eds.). (1976). The forty-nine percent majority: The male sex role. AddisonWesley Publishing Company, ISBN 0201014483, 9780201014488, 338 pages.

Dolan, E. D., Mohr, D., Lempa, M., Joos, S., Fihn, S. D., Nelson, K. M., \& Helfrich, C. D. (2015). Using a single item to measure burnout in primary care staff: a psychometric evaluation. Journal of general internal medicine, 30(5), 582-587.

Eagle, B. W., Miles, E. W., \& Icenogle, M. L. (1997). Interrole conflicts and the permeability of work and family domains: Are there gender differences? Journal of Vocational behavior, 50(2), 168-184.

Engemann, K., \& Owyang, M. 2006. Social changes lead married women into labor force. The Regional Economist, (Apr), 10-11.

Evers, W. J., Tomic, W., \& Brouwers, A. (2004). Burnout among teachers: Students' and teachers' perceptions compared. School Psychology International, 25(2), 131-148.

Ferrant, G., Pesando, L. M., \& Nowacka, K. (2014). Unpaid Care Work: The missing link in the analysis of gender gaps in labour outcomes. Boulogne Billancourt: OECD Development Center.

Ford, M. T., Heinen, B. A., \& Langkamer, K. L. (2007). Work and family satisfaction and conflict: a metaanalysis of cross-domain relations. Journal of applied psychology, 92(1), 57.

Greenglass, E. R. (1991). Burnout and gender: theoretical and organizational implications. Canadian Psychology, 32, 562-574.

Greenglass, E. R., Burke, R. J., \& Moore, K. A. (2003). Reactions to increased workload: Effects on professional efficacy of nurses. Applied Psychology: An International Review, 52(4), 80-597.

Gunnigle, P., Lavelle, J. \& Monaghan, S. (2013). Weathering the storm? Multinational companies and human resource management through the global financial crisis. International Journal of Manpower, 34(3), 214-231.

Gutek, B. A., Searle, S., \& Klepa, L. (1991). Rational versus gender role explanations for work-family conflict. Journal of applied psychology, 76(4), 560.

Halbesleben, J. B. R., \& Demerouti, E. (2005). The construct validity of an alternative measure of burnout: Investigating the English translation of the Oldenburg Burnout Inventory. Work Stress, 19, 208-220.

Hakanen, J. J., \& Schaufeli, W. B. (2012). Do burnout and work engagement predict depressive symptoms and life satisfaction? A three-wave seven-year prospective study. Journal of affective disorders, 141 (2-3), 415-424.

Heggeness, M. L. (2020). Estimating the immediate impact of the COVID-19 shock on parental attachment to the labor market and the double bind of mothers. Review of Economics of the Household, 18(4), 1053-1078.

Hipple, S. F. (2016). Labor force participation: what has happened since the peak. Monthly Lab. Rev, 139, 1.

Houtman, I., \& Blatter, B. (2005). Predicting return to work in employees absent because of psychological problems. The European Health Psychologist, 2, 8-12.

Howard, V. H. (1990). Family members in the work force. Monthly Labor Review, 113(3), 14-19.

Huebener, M., Waights, S., Spiess, C. K., Siegel, N. A., \& Wagner, G. G. (2021). Parental well-being in times of Covid-19 in Germany. Review of Economics of the Household, 19(1), 91-122.

Hyde, J. S. (2005). The gender similarities hypothesis. American psychologist, 60(6), 581. 
Jann, B. (2008). The Blinder-Oaxaca decomposition for linear regression models. The Stata Journal, 8(4), 453-479.

Jawahar, I. M., Stone, T. H., \& Kisamore, J. L. (2007). Role conflict and burnout: the direct and moderating effects of political skill and perceived organizational support on burnout dimensions. International Journal of Stress Management, 14, 142-159.

Kristensen, T. S., Borritz, M., Villadsen, E., \& Christensen, K. B. (2005). The Copenhagen Burnout Inventory: a new tool for the assessment of burnout. Work Stress, 19, 192-207.

Johnson, S. J., Willis, S. M., \& Evans, J. (2019). An examination of stressors, strain, and resilience in academic and non-academic UK university job roles. International Journal of Stress Management, 26 (2), 162

Lingard, H. (2003). The impact of individual and job characteristics on'burnout'among civil engineers in Australia and the implications for employee turnover. Construction Management \& Economics, 21 (1), 69-80.

Liu, L., MacPhail, F., \& Dong, X. Y. (2018). Gender, work burden, and mental health in post-reform China. Feminist Economics, 24(2), 194-217.

Livingston, B., \& Judge, T. (2008). Emotional responses to work-family conflict: an examination of gender role orientation among working men and women. Journal of Applied Psychology, 93(1), 207-216.

MacDonald, W. (2003). The impact of job demands and workload on stress and fatigue. Australian Psychologist, 38(2), 102-117.

MacDonald, M., Phipps, S., \& Lethbridge, L. (2005). Taking its toll: the influence of paid and unpaid work on women's well-being. Feminist Economics, 11(1), 63-94.

Maarit, T. F., Rantanen, J., Hyvönen, K., Mäkikangas, A., Huhtala, M., Pihlajasaari, P., \& Kinnunen, U. (2013). The 9-item Bergen Burnout Inventory: Factorial Validity Across Organizations and Measurements of Longitudinal Data. Industrial Health, 52(2), 102.

Maslach, C., Schaufeli, W. B., \& Leiter, M. P. (2001). Job burnout. Annual review of psychology, 52(1), 397-422.

Maslach, C., \& Leiter, M. P. (2016). Understanding the burnout experience: recent research and its implications for psychiatry. World Psychiatry, 15, 103-111.

Maslach, C., Leiter, M. P., \& Schaufeli, W. (2008). Measuring burnout. In The Oxford handbook of organizational well-being. Edited by Susan Cartwright and Cary L. Cooper, Print Publication Date: Nov 2008, Online Publication Date: Sep 2009, https://doi.org/10.1093/oxfordhb/9780199211913. 003.0005 .

Maslach, C., Jackson, S. E., Leiter, M. P., Schaufeli, W. B., \& Schwab, R. L. (1986). Maslach burnout inventory (pp. 3463-3464). Palo Alto, CA: Consulting psychologists press. Vol. 21.

Malach-Pines, A., \& Ronen, S. (2016). Gender differences in burnout: a literature review. In A. C. Antoniou \& C. L. Copper editors., New directions in organizational psychology and behavioral medicine (pp. 107-22). New York, NY: Routledge.

Messner, M. A. (2000). Barbie girls versus sea monsters: children constructing gender. Gender \& society, 14(6), 765-784.

Michel, J. S., \& Hargis, M. B. (2008). Linking mechanisms of work-family conflict and segmentation. Journal of Vocational Behavior, 73(3), 509-522.

Nahrgang, J. D., Morgeson, F. P., \& Hofmann, D. A. (2011). Safety at work: a meta-analytic investigation of the link between job demands, job resources, burnout, engagement, and safety outcomes. $J$ Appl Psychol, 96, 71-94.

Norlund, S., Reuterwall, C., Höög, J., Janlert, U., \& Järvholm, L. S. (2015). Work situation and selfperceived economic situation as predictors of change in burnout-a prospective general populationbased cohort study. BMC public health, 15(1), 329.

Oaxaca, R. (1973). Male-female wage differentials in urban labor markets. International economic review, 14(3), 693-709.

Parker, S. K., Chmiel, N., \& Wall, T. D. (1997). Work characteristics and employee well-being within a context of strategic downsizing. Journal of occupational health psychology, 2(4), 289.

Pines, A. M., \& Aronson, E. (1988). Career Burnout: Causes and Cures. New York, NY: The Free Press.

Purvanova, R. K., \& Muros, J. P. (2010). Gender differences in burnout: A meta-analysis. Journal of vocational behavior, 77(2), 168-185.

Qi, L., \& Dong, X. Y. (2016). Unpaid care work's interference with paid work and the gender earnings gap in China. Feminist Economics, 22(2), 143-167.

Rittenour, C. E., Colaner, C. W., \& Odenweller, K. G. (2014). Mothers' identities and gender socialization of daughters. Southern Communication Journal, 79(3), 215-234. 
Ronen, S. and Malach Pines, A. (2008), "Gender differences in engineers' burnout", Equal Opportunities International, Vol. 27 No. 8, pp. 677-691. https://doi.org/10.1108/02610150810916749.

Schaufeli, W. B., Bakker, A. B., \& Salanova, M. (2006). The measurement of work engagement with a short questionnaire: a cross-national study. Educational and psychological measurement, 66(4), 701-716.

Schaufeli, W. B., Leiter, M. P., \& Maslach, C. (2009). Burnout: 35 years of research and practice. Career development international, 14(3), 204-220.

Senécal, C., Vallerand, R. J., \& Guay, F. (2001). Antecedents and outcomes of work-family conflict: toward a motivational model. Personality and Social Psychology Bulletin, 27(2), 176-186.

Shirom, A. (1989). Burnout in work organizations. In C. L. Cooper \& I. Robertson (Eds.), International Review of Industrial and Organizational Psychology (pp. 25-48). New York, NY: Wiley.

Suar, D., \& Gochhayat, J. (2016). Influence of biological sex and gender roles on ethicality. Journal of Business Ethics, 134(2), 199-208.

Sulsky, L., \& Smith, C. S. (2005). Work stress. Wadsworth Publishing Company. Publisher Thomson/ Wadsworth, ISBN 0534575765, 9780534575762 , Length 317 pages.

Tamres, L., Janicki, D., \& Helgeson, V. (2002). Sex differences in coping behavior: a meta-analytic review and an examination of relative coping. Personality and Social Psychology Review, 6, 2-30.

Templeton, K., Bernstein, C., Sukhera, J., Nora, L. M., Newman, C., Burstin, H., Guille, C., Lynn, L., Schwarze, M. L., Sen, S., \& Busis, N. (2019). Gender-based differences in burnout: Issues faced by women physicians. NAM Perspectives. Washington, DC: Discussion Paper, National Academy of Medicine. 10.31478/201905a

Toker, S., Shirom, A., Shapira, I., Berliner, S., \& Melamed, S. (2005). The association between burnout, depression, anxiety, and inflammation biomarkers: C-reactive protein and fibrinogen in men and women. Journal of Occupational Health Psychology, 10, 344-362.

Watts, J., \& Robertson, N. (2011). Burnout in university teaching staff: a systematic literature review. Educational Research, 53(1), 33-50.

Zani, B., \& Pietrantoni, L. (2001). Gender differences in burnout, empowerment and somatic symptoms among health professionals: moderators and mediators. Equal Opportunities International, 20, 39-48. 